\title{
PENGARUH LEGUM PENUTUP TANAH TERHADAP PERTUMBUHAN SEMAI MAHONI (Swietenia macrophylla) PADA TANAH MARGINAL
}

\author{
Puji Lestari', Eny Faridah², Cahyono Agus Dwi Koranto ${ }^{3}$ \\ ${ }^{1}$ Program Studi Pengelolaan Hutan/Departemen Teknologi Hayati dan Veteriner/Sekolah Vokasi, Universitas Gadjah Mada, Indonesia \\ Email: ${ }^{1}$ pujilestari@ugm.ac.id \\ ${ }^{2,3}$ Departemen Silvikultur/Fakultas Kehutanan, Universitas Gadjah Mada, Indonesia \\ Email: ${ }^{2}$ enyfaridah@ugm.ac.id, ${ }^{3}$ acahyono@ugm.ac.id
}

\begin{abstract}
Indonesia has large area of marginal land including coast sandy soil and post coal mining soil areas. Reclamation process for marginal land needs long time and high cost, hence, strategic treatments are necessary to reduce both time and cost. This research aims to analyze the effects of media (coast sandy soil, alluvial deposit, and post coal mining soil) and legume cover crop Centrocema pubescens on the growth of mahogany seedlings. This research was conducted at green house for 3 months using Completely Randomized Design (CRD) with $3 \times 2$ factorials and 3 replications. The first factor was marginal soil (three levels: coast sandy soil, post coal mining soil, and alluvial deposit as reference) while the second factor was the application of legume cover crop (two levels: apply and not apply). Variables observed were the height, diameter, biomass, and nutrient content of mahogany seedlings. The results showed that the growth of mahogany in sandy soil media is the best though nutrient content in that media is the lowest. It was caused reduction of salinity from that media. While, up to 3 months old, C. pubescens grew competitively.
\end{abstract}

Keywords: alluvial deposit, coast sandy soil, Centrocema pubescens, post coal mining soil.

\section{PENDAHULUAN}

Tanah marginal merupakan tanah yang memiliki mutu rendah karena adanya beberapa faktor pembatas seperti topografi yang miring, dominasi bahan induk, kandungan unsur hara, dan bahan organik yang sedikit, kadar lengas yang rendah, $\mathrm{pH}$ yang terlalu rendah atau terlalu tinggi, bahkan terdapat akumulasi unsur logam yang bersifat meracun bagi tanaman (Handayani dan Prawito, 2006; Widyati, 2008; Yuwono, 2009; Kanzler, 2015). Menurut Suprapto (2002), di Indonesia terdapat tanah marginal yang luas, mencapai 89,5 juta ha, termasuk di dalamnya tanah pasir pantai dan bekas tambang batu bara. Sampai saat ini penanganan terhadap lahan marginal tersebut masih minim (Yuwono, 2009). Padahal, dengan banyaknya konversi lahan pertanian dan kehutanan ke sektor lain menuntut upaya reklamasi tanah marginal agar menjadi lebih produktif. Kegiatan reklamasi umumnya membutuhkan biaya yang besar (Dariah et al., 2010; Pohan, 2014; Suprapto, 2011) dan waktu yang lama (Patiung et al., 2011; Subowo, 2011).

Kegiatan revegetasi di setiap tanah marginal memiliki faktor pembatasnya masing-masing. Pada tanah bekas tambang batu bara, limbah kegiatan penambangan berupa air asam tambang mengakibatkan $\mathrm{pH}$ tanah menjadi sangat rendah (Susilo et al., 2010; Wijaya, 2010; Hamdani dan Senjaya, 2011; Sulistyo, 2011; Said, 2014). Pada tanah pasir pantai, dominasi pasir mengakibatkan tanah mudah meloloskan air. Selain itu, kadar salinitas dan suhu yang tinggi, tiupan angin yang kencang serta ketersediaan unsur hara yang rendah juga menjadi faktor pembatas kegiatan revegetasi.

Secara teori, kegiatan reklamasi di lahan bekas tambang batu bara dilakukan melalui beberapa tahapan. Tahap pertama yang harus dilakukan adalah menanam cover crop (penutup tanah). Tahap selanjutnya adalah penanaman jenis pioner yang cepat tumbuh (fast growing species). Setelah itu, baru dilakukan pengkayaan dengan jenis-jenis komersil yang umumnya pertumbuhannya lambat (slow growing species). Namun dalam praktiknya, penanaman penutup tanah dan tanaman keras dilakukan secara bersamaan untuk mengefisienkan pekerjaan di lapangan. Pada tanah pasir pantai, faktor pembatas di lahan tersebut diatasi dengan terlebih dahulu menanam tanaman pemecah angin (wind breaker). Sifat fisik dan kimia tanah dapat diperbaiki dengan menambahkan bahan organik.

Mahoni (Swietenia macrophylla) merupakan salah satu jenis komersil yang digunakan untuk revegetasi lahan bekas tambang batu bara, seperti yang dilakukan di PT Berau Coal, Kalimantan Timur. Selain itu menurut Harjadi dan Octavia (2008) mahoni juga dapat ditanam di daerah pantai dengan posisi di belakang cemara udang dan pandan. Krisnawati et al. (2011) menyebutkan bahwa mahoni memiliki toleransi yang luas terhadap kondisi tanah dan lingkungan. Namun demikian, pertumbuhan mahoni tetap lebih optimal pada tapak yang subur.

Penggunaan legum penutup tanah untuk perbaikan kualitas maupun konservasi tanah sudah banyak dilakukan di lahan bekas tambang dan perkebunan kelapa sawit, tetapi pada lahan pasir pantai kegiatan ini belum banyak dilakukan. 
Namun demikian, jika penggunaan legum penutup tanah dapat memberikan kontribusi yang positif terhadap produktivitas lahan, maka teknologi ini sangat prospektif untuk dikembangkan. Salah satu jenis penutup tanah yang dapat dipilih untuk meningkatkan kesuburan tanah adalah Centrocema pubescens (Hidayati et al., 2006; Syarif et al., 2007; Refliaty et al., 2009; Mutalib dan Pandu, 2012; Adrialin et al., 2014). Selama ini, dampak positif legum penutup tanah terhadap kesuburan tanah diketahui melalui mekanisme pemberian input biomassa, berupa guguran daun yang ketika terdekomposisi menyumbang unsur hara bagi tanah (Nusyirwan, 2014; Prayudyaningsih et al., 2015). Mekanisme tersebut tidak dapat terjadi ketika fase awal pertumbuhan legum penutup tanah, dimana pada fase tersebut legum penutup tanah masih mengalami proses pertumbuhan dan belum menggugurkan daun.

Informasi mengenai pengaruh $C$. pubescens pada fase awal pertumbuhannya terhadap mahoni yang ditanam secara bersamaan pada tanah marginal masih sedikit. Xiao et al. (2004) menyebutkan bahwa legum penutup tanah dapat mentransfer nitrogen pada tanaman pokok melalui kontak akar, sedangkan Baon dan Anugrina (2006) menyatakan bahwa legum penutup tanah dapat bersifat kompetitif terhadap pertumbuhan tanaman pokok karena bersaing dalam memperoleh nutrisi dari dalam tanah. Oleh sebab itu, penelitian ini menjadi penting dilakukan untuk mengidentifikasi apakah pada masa pertumbuhan legum penutup tanah sudah mampu berkontribusi positif atau justru bersifat kompetitif terhadap pertumbuhan semai mahoni.

Dalam penerapannya legum penutup tanah digunakan dalam kegiatan penanaman di lapangan (Allorerung et al., 2010; Nugroho et al., 2010; Janudianto et al., 2013), tetapi untuk membatasi faktor lingkungan yang mempengaruhi interaksi tanaman pokok dengan legum penutup tanah, maka penelitian dilakukan secara terkontrol dalam polibag di rumah kaca. Dengan demikian, mekanisme pengaruh legum penutup tanah terhadap ketersediaan unsur hara pada tanah marginal serta pertumbuhan semai mahoni dapat diamati dengan lebih baik.

Penelitian ini bertujuan untuk menganalisis pengaruh media tanam (pasir pantai, endapan aluvial, dan bekas tambang batu bara) dan legum penutup tanah jenis C. pubescens terhadap pertumbuhan semai mahoni. Hasil penelitian ini diharapkan mampu memberikan informasi mengenai respon semai mahoni terhadap berbagai cekaman yang terdapat pada tanah marginal serta pengaruh legum penutup tanah (C. pubescens) terhadap pertumbuhan semai mahoni dalam rangka reklamasi lahan sehingga lahan menjadi lebih produktif.

\section{BAHAN DAN METODE PENELITIAN}

Penelitian dilakukan di rumah kaca selama 3 bulan dari bulan November 2014 hingga Februari 2015 di Rumah Kaca Laboratorium Silvikultur Intensif, Fakultas Kehutanan UGM. Rancangan yang digunakan dalam penelitian ini adalah CRD (Completely Randomized Design) pola faktorial 3 x 2 dengan tiga ulangan. Faktor pertama adalah media yang meliputi tanah pasir pantai, bekas tambang, dan sebagai pembanding digunakan media normal yang biasa digunakan untuk memproduksi bibit di Persemaian Silvikultur Intensif, yaitu tanah endapan aluvial dengan asumsi media tersebut tidak marginal. Sifat kimia tanah ketiga media tersebut disajikan pada Tabel 1, sedangkan fraksi penyusunnya disajikan pada Tabel 2. Faktor kedua adalah penggunaan dan tanpa penggunaan legum penutup tanah. Variabel pada penelitian ini meliputi pertumbuhan (tinggi, diameter, dan biomassa) dan kandungan unsur hara pada jaringan semai mahoni serta kandungan sifat kimia tanah yang diukur sebelum perlakuan dan sesudah perlakuan (akhir penelitian).

Pengambilan media pasir pantai pantai dilakukan di Pantai Goa Cemara, Desa Gading Sari, Kecamatan Sanden, Kabupaten Bantul, DIY, sedangkan tanah bekas tambang diambil dari lokasi back filling Site Lathi, PT. Berau Coal, Kalimantan Timur. Sementara itu, tanah endapan aluvial (ordo inseptisol) diambil dari daerah Sedayu, Bantul, Yogyakarta.

Tabel 1. Sifat kimia tanah pada setiap media

\begin{tabular}{lcccccc}
\hline \multicolumn{1}{c}{ Media } & $\mathbf{p H}$ & $\begin{array}{c}\mathbf{N H}_{4}^{+} \\
(\mathbf{p p m})\end{array}$ & $\begin{array}{c}\mathbf{N O}_{3}^{-} \\
(\mathbf{p p m})\end{array}$ & $\begin{array}{c}\mathbf{P}_{2} \mathbf{O}_{\mathbf{5}} \\
(\mathbf{p p m})\end{array}$ & $\begin{array}{c}\mathbf{K}^{+} \\
(\mathbf{m e} \mathbf{1 0 0 g})\end{array}$ & $\begin{array}{c}\text { KTK } \\
(\mathbf{m e} \mathbf{1 0 0 g})\end{array}$ \\
\hline Pasir Pantai & 6,3 & 24 & 146 & 1 & 0,09 & 0,70 \\
Endapan Aluvial & 7,4 & 110 & 189 & 116 & 0,90 & 9,64 \\
Bekas Tambang & 3,7 & 43 & 29 & 13 & 0,03 & 0,20 \\
\hline
\end{tabular}

Tabel 2. Perbandingan fraksi penyusun media

\begin{tabular}{lccc}
\hline \multicolumn{1}{c}{ Media } & Pasir (\%) & Debu (\%) & Lempung (\%) \\
\hline Pasir Pantai & 98 & 1 & 1 \\
Endapan Aluvial & 73 & 23 & 4 \\
Bekas Tambang & 18 & 30 & 52 \\
\hline
\end{tabular}


Sebelum ditanam, biji mahoni terlebih dahulu dikecambahkan di dalam bak tabur. Setelah 1 bulan semai mahoni yang telah memiliki 4 buah daun dengan tinggi rata-rata $19 \mathrm{~cm}$ dan diameter 1,5 mm disapih pada polibag berukuran $25 \mathrm{x}$ $30 \mathrm{~cm}$ yang telah diisi media setinggi $17 \mathrm{~cm}$. Biji C. pubescens sebelumnya juga dikecambahkan terlebih dahulu (selama 2 minggu). Waktu pengaplikasian legum bersamaan dengan penyapihan semai mahoni di mana setiap pot diberi tiga $C$. pubescens dengan posisi mengelilingi semai mahoni. Pengukuran tinggi tanaman dilakukan setiap 2 minggu sekali. Tinggi diukur dari permukaan media sampai pangkal pertumbuhan daun yang paling muda. Pengukuran diameter dilakukan setiap 1 bulan sekali. Diameter diukur pada posisi $1,5 \mathrm{~cm}$ di atas permukaan media.

Analisis data hasil pengukuran tinggi, diameter serta biomassa semai mahoni dilakukan dengan sidik ragam pada taraf kesalahan 5\% dan 1\% menggunakan Program SAS 9.0. Jika perlakuan berpengaruh nyata, dilakukan Uji Lanjut DMRT (Duncan Multiple Range Test). Perubahan sifat kimia tanah dianalisis secara deskriptif kuantitatif.

\section{Hasil dan pembahasan}

\subsection{Pengaruh Perlakuan terhadap Tinggi Semai}

Hasil analisis varian terhadap tinggi akhir semai mahoni umur 3 bulan menunjukkan bahwa aplikasi C. pubescens tidak berpengaruh nyata terhadap rerata tinggi semai mahoni. Namun demikian, tampak bahwa semai mahoni yang ditanam bersama dengan $C$. pubescens memiliki tinggi yang lebih rendah $(24,45 \mathrm{~cm})$ dibandingkan dengan semai mahoni yang ditanam tanpa C. pubescens (24,96 cm). Kondisi ini berbeda dengan penelitian Hasanah et al. (2014) dimana legum penutup tanah Desmodium spp. yang ditanam bersama dengan semai jabon selama 3 bulan justru mampu memberikan dampak positif dengan meningkatkan pertumbuhan tinggi semai jabon (Anthocephalus cadamba), sedangkan pada penelitian Baon dan Anugrina (2006) tinggi kakao berumur 5 bulan yang diberi perlakuan eksudat akar dari Arachis pintoi lebih tinggi dibandingkan dengan perlakuan kontrol, namun perbedaan tingginya tidak signifikan.

Tabel 3. Analisis varian rerata tinggi, diameter, dan biomassa semai mahoni

\begin{tabular}{lcccc}
\hline Sumber variasi & Derajat bebas & Tinggi & Diameter & Biomassa \\
\hline Legum & 1 & tn & $* *$ & $* *$ \\
Media & 2 & $* *$ & $*$ & th \\
Legum x Media & 2 & tn & th & th \\
Galat & 12 & & & \\
Total & 17 & & & \\
\hline
\end{tabular}

Keterangan: $\mathrm{tn}=$ tidak berbeda nyata; $*=$ berbeda nyata pada taraf kesalahan $5 \%$; **= berbeda nyata pada taraf kesalahan $1 \%$.

Di sisi lain, media berpengaruh sangat nyata terhadap rerata tinggi semai mahoni (Tabel 3). Tinggi semai mahoni di ketiga media tersebut lebih rendah dibandingkan dengan tinggi semai mahoni yang ditanam pada media tanah yang subur (top soil, pasir, dan pupuk kompos dengan perbandingan 8:1:1) dengan pupuk dasar TSP 1 gram dan perlakuan NPK 0,6 gram. Semai mahoni dengan perlakuan tersebut dapat mencapai tinggi sebesar $42 \mathrm{~cm}$ selama 3 bulan (Adinugraha, 2012). Menurut Wasis dan Sandrasari (2011) pertumbuhan tinggi semai mahoni yang ditanam pada media bekas tambang emas akan lebih baik, jika diberi perlakuan pupuk kompos. Pemberian pupuk kompos sebesar 30 gram dapat meningkatkan pertumbuhan tinggi semai mahoni sebesar 40,7\% selama 4 bulan. Lisda et al. (2016) menyatakan bahwa penambahan mikoriza (Glomus mosseae) sebanyak 20 gram/polibag pada media tanah, pasir, dan arang tempurung kelapa dengan perbandingan 3:1:1 dapat meningkatkan pertumbuhan tinggi semai mahoni sebesar 2,7 cm selama 2 bulan. Dengan demikian, tambahan pupuk sangat diperlukan mahoni yang ditanam pada tanah marginal untuk mendapatkan pertumbuhan yang optimal.

Tabel 4. Pengaruh media terhadap tinggi, diameter, dan biomassa semai mahoni

\begin{tabular}{lccc}
\hline \multicolumn{1}{c}{ Media } & Tinggi $(\mathbf{c m})$ & Diameter $(\mathbf{m m})$ & Biomassa $(\mathbf{g})$ \\
\hline Pasir Pantai & $25,87^{\mathrm{a}}$ & $3,61^{\mathrm{a}}$ & $7,53^{\mathrm{a}}$ \\
Endapan Aluvial & $22,47^{\mathrm{b}}$ & $3,30^{\mathrm{b}}$ & $7,65^{\mathrm{a}}$ \\
Bekas Tambang & $25,77^{\mathrm{a}}$ & $3,47^{\mathrm{ab}}$ & $7,34^{\mathrm{a}}$ \\
\hline
\end{tabular}

Keterangan : Angka yang diikuti huruf yang berbeda pada kolom yang sama berbeda nyata berdasarkan Uji DMRT.

Meskipun kandungan unsur hara tersedia (nitrogen, fosfor, dan kalium) serta kapasitas tukar kation pada media endapan aluvial lebih tinggi dibandingkan dengan kedua media yang lain (Tabel 1), akan tetapi pertumbuhan tinggi semai 
mahoni pada endapan aluvial paling rendah dibandingkan kedua tanah marginal. Hal tersebut diduga karena salinitas pada media endapan aluvial lebih tinggi dibandingkan kedua media yang lain (Gambar 1 pada pengukuran sesudah perlakuan). Sarhan et al. (2006) menyebutkan daya tahan mahoni afrika menurun seiring dengan meningkatnya salinitas. Salinitas secara signifikan menurunkan tinggi, diameter, dan panjang akar tanaman tersebut.

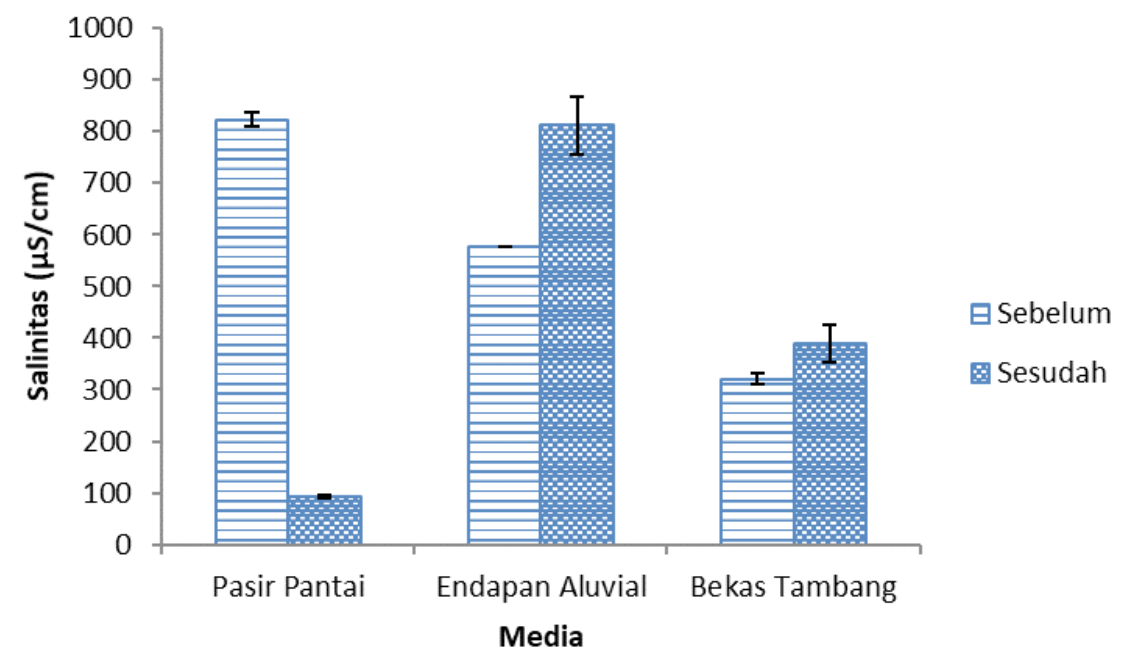

Gambar 1. Salinitas media sebelum dan sesudah perlakuan

Salinitas pada media pasir pantai sebelum penanaman $\left(823 \mu \mathrm{S} \mathrm{cm}^{-1}\right)$ lebih tinggi dibandingkan dengan media endapan aluvial $\left(577 \mu \mathrm{S} \mathrm{cm}^{-1}\right)$, akan tetapi karena pengaruh penyiraman semai selama penelitian, maka sesudah penanaman (akhir penelitian) salinitas pada media pasir pantai menurun drastis 86-89\% (Gambar 1). Menurut Rachman et al. (2008), ion-ion pembentuk salinitas tanah seperti klorida $\left(\mathrm{Cl}^{-}\right)$dan natrium $\left(\mathrm{Na}^{+}\right)$bersifat sangat mudah terlindi, khususnya pada tanah yang bertekstur kasar (didominasi fraksi pasir) karena pasir tidak memiliki muatan sehingga tidak dapat mengikat ion.

\subsection{Pengaruh Perlakuan terhadap Diameter Semai}

Hasil analisis varian menunjukkan bahwa C. pubescens berpengaruh sangat nyata terhadap diameter semai mahoni. Pada Tabel 5 terlihat bahwa diameter semai mahoni yang ditanam dengan legum (3,27 mm) lebih kecil dibandingkan dengan yang ditanam tanpa legum (3,65 mm). Pujiyanto et al. (2003) juga menyebutkan bahwa pertumbuhan diameter batang kakao yang ditanam bersama dengan Arachis pintoi dan Calopogonium caeruleum secara nyata menurun 14-20\%.

Tabel 5. Pengaruh legum terhadap diameter dan biomassa semai mahoni

\begin{tabular}{lccc}
\hline \multicolumn{1}{c}{ Media } & Tinggi $(\mathbf{c m})$ & Diameter $(\mathbf{m m})$ & Biomassa (g) \\
\hline Dengan Legum & $24,45^{\mathrm{a}}$ & $3,27^{\mathrm{a}}$ & $6,58^{\mathrm{a}}$ \\
Tanpa Legum & $24,96^{\mathrm{a}}$ & $3,65^{\mathrm{b}}$ & $8,35^{\mathrm{b}}$ \\
\hline
\end{tabular}

Keterangan: Angka yang diikuti huruf yang berbeda pada kolom yang sama berbeda nyata berdasarkan uji DMRT. 


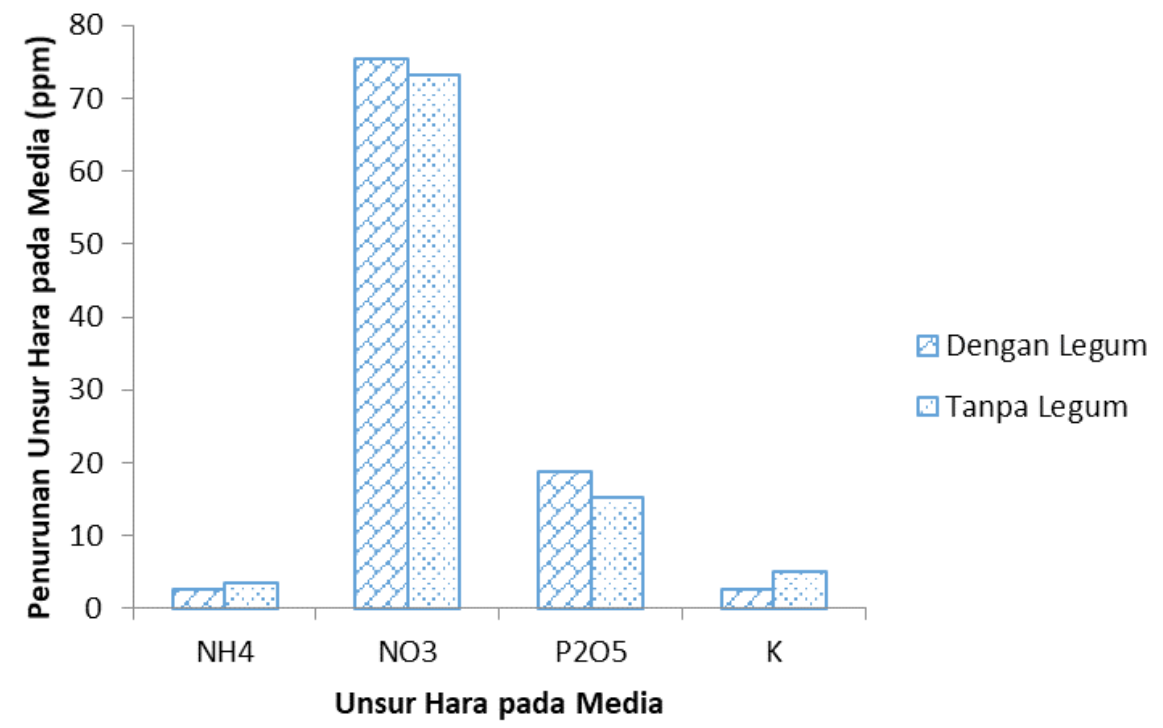

Gambar 2. Penurunan unsur hara dari media tanam mahoni

Dari Gambar 2 tampak bahwa kandungan nitrat $\left(\mathrm{NO}_{3}^{-}\right)$pada media yang ditanami semai mahoni dengan legum berkurang lebih banyak dibandingkan dengan semai mahoni tanpa legum. Namun demikian, kandungan N pada jaringan semai mahoni dengan legum ternyata lebih rendah dibandingkan dengan mahoni tanpa legum (Gambar 3). Hal tersebut mengindikasikan bahwa $\mathrm{N}$ pada tanah selain diserap oleh semai mahoni juga diserap oleh tanaman legum. Utama (2008) menyebutkan bahwa dalam kondisi tercekam, seperti keberadaan Al yang berlebih penyerapan nitrat oleh $C$. pubescens tetap berlangsung secara normal. Indikasi yang sama juga terjadi pada unsur $\mathrm{P}$, dimana $\mathrm{P}$ pada media semai mahoni dengan legum berkurang lebih banyak dibandingkan dengan pada semai mahoni tanpa legum, akan tetapi kandungan P pada jaringan semai mahoni dengan legum lebih rendah dibandingkan dengan semai mahoni tanpa legum.

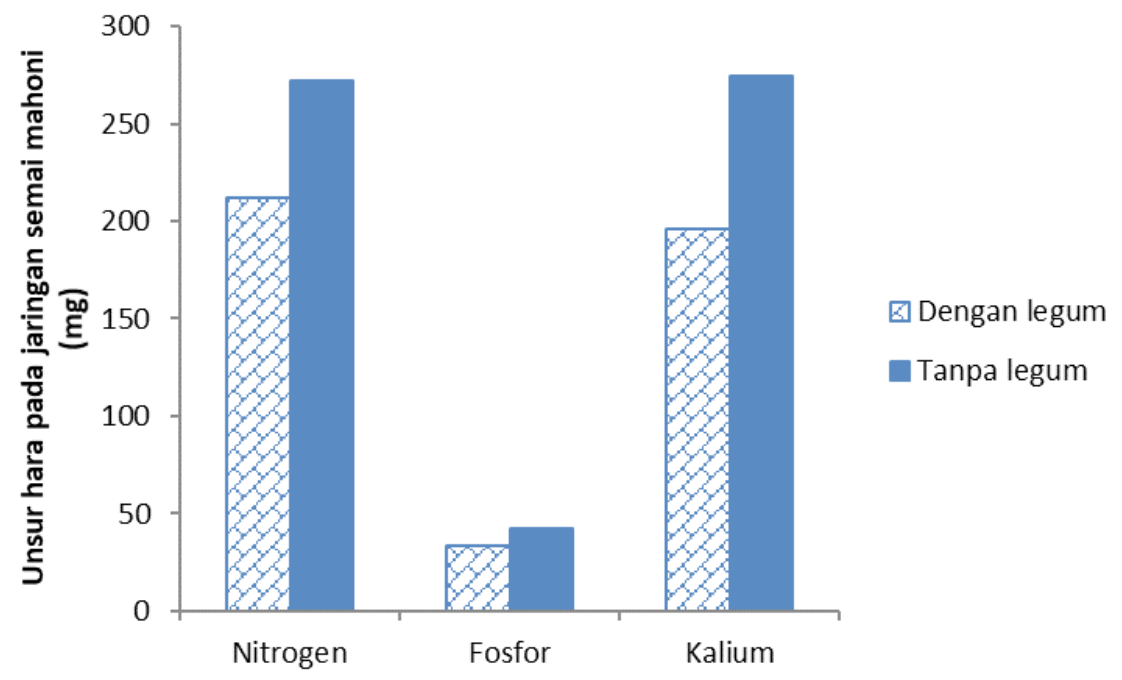

Gambar 3. Kandungan unsur hara pada jaringan mahoni

Viégas et al. (2012) menyebutkan bahwa unsur makro esensial yang paling membatasi pertumbuhan semai mahoni adalah N, diikuti secara berturut-turut oleh $\mathrm{P}, \mathrm{Ca}, \mathrm{Mg}, \mathrm{K}$, dan $\mathrm{S}$. Defisiensi N menyebabkan penurunan biomassa semai mahoni hingga 8,4 kali lebih rendah daripada kondisi normal, defisiensi P menurunkan 4,9 kali, sedangkan defisiensi K menurunkan 2,2 kali. Wallau et al. (2008) juga menyebutkan bahwa pengurangan biomassa semai mahoni, khususnya disebabkan kekurangan oleh unsur N, K, Ca, dan Cu. Sementara Souza et al. (2010) mengungkapkan bahwa pada tanah asam yang ketersediaan bahan organiknya banyak, P merupakan unsur hara yang paling membatasi 
pertumbuhan mahoni. Namun demikian, Tucci et al. (2011) menyebutkan bahwa penambahan pupuk $\mathrm{N}$ hingga dosis $200 \mathrm{~kg} / \mathrm{ha}$ dan pupuk P hingga $400 \mathrm{~kg} / \mathrm{ha}$ tidak berpengaruh terhadap petumbuhan semai mahoni, sedangkan aplikasi pupuk K hingga dosis $200 \mathrm{~kg} / \mathrm{ha}$ mampu sedikit meningkatkan pertumbuhannya. Berdasarkan uraian di atas, tampaknya $\mathrm{N}$ merupakan faktor pembatas utama bagi pertumbuhan mahoni, sedangkan P dan K tergantung pada masing-masing kondisi spesifik di lapangan.

Hasil analisis varian juga menunjukkan bahwa media berpengaruh signifikan terhadap rerata diameter batang semai mahoni. Tabel 5 menunjukkan bahwa rerata diameter semai mahoni yang paling baik juga terdapat pada media pasir pantai $(3,61 \mathrm{~mm})$, meskipun tidak berbeda signifikan dengan media tanah bekas tambang $(3,47 \mathrm{~mm})$, namun berbeda signifikan dengan media endapan aluvial $(3,30 \mathrm{~mm})$. Sementara itu, antara media tanah bekas tambang dan endapan aluvial tidak ada beda yang signifikan. Pada penelitian ini, kegiatan penyiraman yang dilakukan pada media pasir pantai yang jumlahnya terbatas (dalam polibag) mengakibatkan cekaman salinitas yang awalnya paling tinggi pada media tersebut menjadi turun secara drastis (Gambar 1) karena teksturnya didominasi oleh pasir (Tabel 2) sehingga mudah meloloskan kandungan garam, berbeda dengan tanah aluvial yang memiliki fraksi debu dan lempung yang lebih banyak (Tabel 2) sehingga kandungan garam pada media tersebut tidak mudah hilang saat penyiraman. Dengan demikian, diameter semai mahoni pada media pasir lebih besar karena cekaman salinitas hilang, sedangkan pada media endapan aluvial masih terdapat cekaman salinitas (Gambar 2 pengamatan sesudah perlakuan) dan pada media bekas tambang terdapat cekaman $\mathrm{pH}$ rendah (Tabel 1).

Diameter semai mahoni di ketiga media tersebut lebih rendah dibandingkan dengan diameter semai mahoni yang ditanam pada media tanah yang subur (top soil, pasir, dan pupuk kompos dengan perbandingan 8:1:1) dengan pupuk dasar TSP 1 gram dan perlakuan NPK 0,6 gram. Semai mahoni dengan perlakuan tersebut dapat mencapai diameter sebesar 5,15 $\mathrm{mm}$ selama 3 bulan (Adinugraha, 2012). Wasis dan Sandrasari (2011) menyebutkan bahwa pertumbuhan diameter semai mahoni yang ditanam pada media bekas tambang emas akan lebih baik jika diberi perlakuan pupuk kompos. Pemberian pupuk kompos sebesar 30 gram dapat meningkatkan pertumbuhan diameter semai mahoni sebesar 17,93\% selama 4 bulan. Menurut Lisda et al. (2016) penambahan mikoriza (Glomus mosseae) sebanyak 20 gram/polibag pada media tanah, pasir, arang kayu Acacia nilotica, dan arang tempurung kelapa dapat meningkatkan pertumbuhan diameter semai mahoni sebesar $0,83 \mathrm{~cm}$ selama 2 bulan

\subsection{Pengaruh Perlakuan terhadap Biomassa Semai}

Analisis varian biomassa mahoni umur 3 bulan menunjukkan bahwa $C$. pubescens berpengaruh sangat nyata terhadap biomassa semai mahoni. Tabel 5 menunjukkan semai mahoni yang ditanam tanpa legum menghasilkan biomassa yang lebih banyak ( $8,35 \mathrm{~g})$ dibandingkan dengan semai mahoni dengan legum $(6,58 \mathrm{~g})$. Hal serupa juga terjadi pada penelitian yang dilakukan oleh Baon dan Anugrina (2006) bahwa aplikasi legum jenis Arachis pintoi pada kakao yang ditanam pada media terbatas (pot) memberikan dampak negatif bagi pertumbuhan kakao. Semakin banyak jumlah legum yang diaplikasikan, berat biomassa batang dan daun kakao semakin kecil. Telah diuraikan pada sub bahasan sebelumnya bahwa dampak negatif C. pubescens diduga kuat akibat persaingan dalam memperoleh unsur hara, bukan karena sifat alelopati dari C. pubescens. Sahid et al. (1993) menyebutkan bahwa C. pubescens tidak bersifat alelopati.

Meskipun pada awal pertumbuhannya $C$. pubescens berpotensi sebagai kompetitor bagi tanaman pokok, namun demikian secara umum penggunaan legum penutup tanah tetap diperlukan dalam kegiatan reklamasi maupun rehabilitasi lahan. Hal tersebut didasarkan pada peran legum penutup di lapangan sebagai penahan erosi serta sumber bahan organik pada tanah marginal (Sumarni et al., 2006; Rosliani et al., 2010; Nusyirwan, 2014; Yani et al., 2016). Selain itu, penelitian di lapangan juga perlu dilakukan untuk mengetahui pengaruh penggunaan C. pubescens terhadap pertumbuhan mahoni pada kondisi media yang lebih luas.

\section{KESIMPULAN}

Berkurangnya cekaman salinitas pada media pasir pantai membuat pertumbuhan semai mahoni pada media pasir pantai lebih baik dibandingkan kedua media yang lain, meskipun kandungan unsur hara pada media tersebut rendah. Pada media yang jumlahnya terbatas (polibag) C. pubescens sampai umur 3 bulan cenderung bersifat kompetitif terhadap semai mahoni. Diameter dan biomassa semai mahoni yang ditanam dengan legum lebih kecil berturut-turut $10,41 \%$ dan $20,96 \%$ dibandingkan dengan semai mahoni yang ditanam tanpa legum. Dengan demikian, sebaiknya penanaman mahoni pada lahan marginal dilakukan setelah C. pubescens mampu menghasilkan input bahan organik bagi perbaikan kualitas lahan. 


\section{DAFTAR PUSTAKA}

Adinugraha, H. A. 2012. Pengaruh Cara Penyemaian dan Pemupukan NPK terhadap Pertumbuhan Bibit Mahoni Daun Lebar di Pesemaian. Jurnal Pemuliaan Tanaman Hutan 6 (1): 1-10. DOI: http://dx.doi.org/10.20886/jpth.2012.6.1.1-10.

Adrialin, G. S., Wawan, dan Y. Venita. 2014. Produksi Biomassa, Kadar N, dan Bintil Akar Berbagai Leguminous Cover Crop (LCC) pada Tanah Dystrudepts. Jom Faperta 1 (2).

Allorerung, D., M. Syakir, Z. Poeloengan, Syafaruddin, dan W. Rumini. (2010). Budidaya Kelapa Sawit. Bogor: Aska Media.

Baon, J. B., dan Y. Anugrina. 2006. Kajian Sifat Kompetisi Tanaman Penutup Tanah Arachis pintoi terhadap Pertumbuhan Tanaman Kakao. Pelita Perkebunan 22: 191-212.

Dariah, A., A. Abdurachman, dan D. Subardja. 2010. Reklamasi Lahan Eks-Penambangan untuk Perluasan Areal Pertanian. Jurnal Sumberdaya 4 (1): 1-12.

Hamdani, A. H dan Senjaya, Y. A. 2011. Geokimia Batuan Penutup (Overburden) Batubara untuk Memprediksi Potensi Air Asam Tambang di Pit 1 IUP PWR, di Daerah Kasai, Kabupaten Berau, Kalimantan Timur. Bulletin of Scientific Contribution GEOLOGY 9 (2): 77-96. DOI: https://doi.org/10.24198/bsc.vol9.yr2011.art8265.

Handayani, I. P., \& P. Prawito. (2006). Tumbuhan Perintis Pemulih Lahan Kritis Kiat Petani Membangun Kesuburan Tanah. Fakultas Pertanian Bengkulu dan KEHATI, Indonesia.

Hasanah, N. I., B. Wasis, dan I. Mansur. 2014. Pengembangan Desmodium spp. sebagai Tanaman Penutup Tanah dalam Reklamasi Lahan Pasca Tambang. Jurnal Silvikultur Tropika 5 (1): 7-12.

Harjadi, B dan D. Octavia. 2008. Penerapan Teknik Konservasi Tanah di Pantai Berpasir untuk Agrowisata. Info Hutan 5 (2): 113-121.

Hidayati, N., F. Syarif, dan T. Juhaeti. 2006. Potensi Centrocema pubescence, Calopogonium mucunoides, dan Micania cordata dalam Membersihkan Logam Kontaminan pada Limbah Penambangan Emas. Biodiversitas 7(1): 4-6.

Janudianto, A. Prahmono, H. Napitupulu, dan S. Rahayu. 2013. Panduan Budidaya Karet untuk Petani Skala Kecil. Rubber cultivation guide for small-scale farmers. Lembar Informasi AgFor 5. Bogor, Indonesia: World Agroforestry Centre (ICRAF) Southeast Asia Regional Program.

Kanzler, M., C. Böhm, dan D. Freese. 2015. Impact of P Fertilisation on the Growth Performance of Black Locust (Robinia pseudoacacia L.) in a Lignite Post-Mining Area in Germany. Ann. For. Res 58: 39-54.

Krisnawati, H., Kallio, M. \& Kanninen, M. (2011). Swietenia macrophylla King: Ecology, Silviculture and Productivity. CIFOR, Bogor, Indonesia.

Lisda, H. Umar, dan Yusran. 2016. Pengaruh Mikoriza dan Arang pada Media Tumbuh terhadap Pertumbuhan Semai Mahoni (Swietenia macrophylla King.). Warta Rimba 4 (1): 119-124.

Mutalib, A dan K. Pandu. 2012. Pemanfaatan Centrosema pubescens sebagai Tanaman Penutup Tanah pada Lahan Kakao. J. Agroplantae 1 (1): 56-66.

Nugroho, P.A., Istianto, N. Siagian, dan Karyudi. 2010. Pengaruh Penanaman Mucuna bracteata terhadap Status Hara dan Pertumbuhan Tanaman Karet Belum Menghasilkan. J. Penelitian Karet 28: 44-54.

Nusyirwan, 2014. Optimalisasi Lahan Suboptimal Melalui Penanaman Mucuna bracteata. Prosiding Seminar Nasional Lahan Suboptimal, Palembang 26-27 September.

Patiung, O., N. Sinukaban, S. D. Tarigan, dan D. Darusman, 2011. Pengaruh Umur Reklamasi Lahan Bekas Tambang Batubara terhadap Fungsi Hidrologis. J. Hidrolitan 2 (2): 60-73.

Pohan, C. A. 2014. Cadangan Reklamasi Pertambangan sebagai Loopholes Pajak dalam Penerapan Prinsip TaxabilityDeductibility. J. Ilmu Administrasi 2:181-198.

Prayudyaningsih, R, E. Faridah, Sumardi, dan B. H. Sunarminto. 2015. Dampak Fasilitatif Tumbuhan Legum Penutup Tanah dan Tanaman Bermikoriza pada Suksesi Primer di Lahan Bekas Tambang Kapur. J. Manusia dan Lingkungan 22 (3): 310-318. 
Pujiyanto, Sudaryono, A. Rachim, S. Sabiham, A. Sastiono, dan J.B. Baon. 2003. Pengaruh Pemupukan Nitrogen dan Fosfor terhadap Kompetisi Antara Bibit Kakao dengan Arachis pintoi dan Calopogonium caeruleum dalam Media Terbatas. Pelita Perkebunan 19:17-27.

Rachman, A., D. Erfandi, dan M.N. Ali. 2008. Dampak Tsunami terhadap Sifat-sifat Tanah Pertanian di NAD dan Strategi Rehabilitasinya. J. Tanah dan Iklim 28: 27-38.

Refliaty, Y. Farni dan S. Intan. 2009. Pengaruh Leguminosa Cover Crop (LCC) terhadap Sifat Fisik Ultisol Bekas AlangAlang dan Hasil Jagung. Jurnal Agronomi 13 (2): 51-56.

Rosliani, R., N. Sumarni, dan I. Sulastrini. 2010. Pengaruh Cara Pengolahan Tanah dan Tanaman Kacang-kacangan sebagai Tanaman Penutup Tanah terhadap Kesuburan Tanah dan Hasil Kubis di Dataran Tinggi. J. Hort 20 (1): 36-44.

Said, N. I. 2014. Teknologi Pengolahan Air Asam Tambang Batubara “Alternatif Pemilihan Teknologi”. Jurnal Air Indonesia 7 (2): 119-138.

Sahid, I., A. Tasrif, S.S. Sastroutomo, and A. Latiff. 1993. Allelopathic Potential of Legume Cover Crops on Selected Weed Species. Plant Protection Quarterly 8: 49-53.

Sarhan, A.Z., M.A. Salem, and L. Soliman. 2006. Effect of Irrigation Water Salinity Levels and Soil Mycorrhizal Fungi Inoculation on Growth of African Mahogany Khaya senegalensis Transplants. Annals of Agricultural Science 44: $625-635$.

Souza, C.A.S.de, C.A.F. Tucci, J.F.da. Silva, and W.O. Ribeiro. 2010. Nutritional Requirements and Growth of Mahogany (Swietenia macrophylla King.) plants. Acta Amazonica 40: 515-522.

Subowo, G. 2011. Penambangan Sistem Terbuka Ramah Lingkungan dan Upaya Reklamasi Pasca Tambang untuk Memperbaiki Kualitas Sumberdaya Lahan dan Hayati Tanah. J. Sumberdaya Lahan 5:83-94.

Sulistyo, T. 2011. Kajian Air Asam di Sekitar Singkapan (Outcrop) Batubara di Kota Balikpapan. Jurnal Ilmiah Politeknik 3 (1): $17-28$.

Sumarni, N., A. Hidayat, dan E. Sumiati. 2006. Pengaruh Tanaman Penutup Tanah dan Mulsa Organik terhadap Produksi Cabai dan Erosi Tanah. J. Hort 16 (3): 197-301.

Suprapto, A. (2002). Land and Water Resources Development in Indonesia. Investment in Land and Water. Bangkok, Thailand.

Suprapto. 2011. Aspek Hukum Tentang Reklamasi Pertambangan Batubara Studi di Kecamatan Satui Tanah Bumbu. FH.UNISBA 8 (3): 189-201.

Susilo, A., Suryanto, S. Sugiarto, \& R. Maharani (ed). (2010). Status Riset Reklamasi Bekas Tambang Batubara. Samarinda: Badan Penelitian dan Pengembangan Kehutanan Balai Besar Penelitian Dipterokarpa.

Syarif, F., N. Hidayati, dan T. Juhaeti. 2007. Potensi Hipertoleransi Calopogonium mucunoides, Centrosema pubescens dan Cajanus cajan yang Tumbuh pada Limbah Penambangan Emas Terkontaminasi Sianida dan Merkuri. Jurnal Biologi Indonesia 4 (4): 239-248. DOI: http://dx.doi.org/10.14203/jbi.v4i4.3251.

Tucci, C.A.F., J.Z.L. Santos, C.H.da.S. Júnior, P.A.de. Souza, I.M.P. Batista, and N. Venturin. 2011. Development of Swietenia macrophylla Seedlings in Response to Nitrogen, Phosphorus and Potassium. Floresta 41: 481-490.

Utama, M.Z.H. 2008. Mekanisme Fisiologi Toleransi Cekaman Aluminium Spesies Legum Penutup Tanah terhadap Metabolisme Nitrat (NO3-), Amonium (NH4+), dan Nitrit (N02-). Bul. Agron 36: 176-180.

Viégas, I.J.M., A.K.S. Lobato, M.F.S. Rodrigues, R.L.M. Cunha, D.A.C.F. Frazão, C.F.O. Neto, H.E.O. Conceição, E.M.S. Guedes, G.A.R. Alves, and S.P. Silva. 2012. Visual Symptoms and Growth Parameters Linked to Deficiency of Macronutrients in Young Swietenia macrophylla, Plants. J. of Food, Agriculture and Environment 10:937-940.

Wasis, B. dan Sandrasari, A. 2011. Pengaruh Pemberian Pupuk Kompos terhadap Pertumbuhan Semai Mahoni (Swietenia macrophylla King.) pada Media Tanah Bekas Tambang Emas (Tailing). Jurnal Silvikultur Tropika 3 (1):109 - 112.

Widyati, E. 2008. Peranan Mikroba Tanah pada Kegiatan Rehabilitasi Lahan Bekas Tambang. Info Hutan, 5:151 - 160. 
Wijaya, R. A. E. 2010. Sistem Pengolahan Air Asam Tambang pada Water Pond dan Aplikasi Model Encapsulation In-Pit Disposal pada Waste Dump Tambang Batubara. J Manusia dan Lingkungan 17 (1): 1-10.

Xiao, Y., L. Li, and F. Zhang. 2004. Effect of Root Contact on Interspecific Competition and N Transfer Between Wheat and Fababean Using Direct and Indirect 15N Techniques. Plant and Soil 262: 45-54.

Yani, M., K. P. Wicaksono dan A. Nugroho. 2016. Pengaruh Pemanfaatan Tanaman Penutup Tanah Orok-Orok (Crotalaria Juncea L.) terhadap Pengendalian Gulma pada Tanaman Jagung (Zea Mays L.) di Musim Hujan. Jurnal Produksi Tanaman 4 (7): 512-519.

Yuwono, N.W. 2009. Membangun Kesuburan Tanah di Lahan Marginal. J. Ilmu Tanah dan Lingkungan 9:137-141. 